\title{
Immobilization of molecular catalysts for artificial photosynthesis
}

\author{
Dong Ryeol Whang*
}

\begin{abstract}
Artificial photosynthesis offers a way of producing fuels or high-value chemicals using a limitless energy source of sunlight and abundant resources such as water, $\mathrm{CO}_{2}$, and/or $\mathrm{O}_{2}$. Inspired by the strategies in natural photosynthesis, researchers have developed a number of homogeneous molecular systems for photocatalytic, photoelectrocatalytic, and electrocatalytic artificial photosynthesis. However, their photochemical instability in homogeneous solution are hurdles for scaled application in real life. Immobilization of molecular catalysts in solid supports support provides a fine blueprint to tackle this issue. This review highlights the recent developments in (i) techniques for immobilizing molecular catalysts in solid supports and (ii) catalytic water splitting, $\mathrm{CO}_{2}$ reduction, and $\mathrm{O}_{2}$ reduction with the support-immobilized molecular catalysts. Remaining challenges for molecular catalyst-based devices for artificial photosynthesis are discussed in the end of this review.
\end{abstract}

Keywords: Artificial photosynthesis, Molecular catalysts, Immobilization, Solar fuel

\section{Introduction}

Natural photosynthesis provides over $99 \%$ of nutrients to the living organisms on earth. At the beginning of food chains, photosynthetic autotrophs, i.e. plants, algae, and bacteria, convert inorganic substances into energyintensive food by using sunlight as an energy source. Through the course of 3.4 billion years [1] nature has selected molecular systems to carry out the photochemical processes. Molecular catalysts have abundant advantages: (i) well defined molecular structure and active center (ii) feasible mechanistic study with the help of various spectroscopic techniques, (iii) maximized active sites in homogeneous solutions, (iv) high tunability of their chemical/physical properties by rational molecular design, etc. [2]. These features inspired the development of molecular catalysts for solar energy transduction in artificial photosynthesis.

The concept of storing the solar energy into higherenergy chemicals is the basis of artificial photosynthesis,

*Correspondence: whang@hnu.kr

Department of Advanced Materials, Hannam University, 34054 Daejeon, Republic of Korea which is dedicated to producing fuels/high-value chemicals such as $\mathrm{H}_{2}$, methane, methanol, or hydrogen peroxide. A number of molecular catalysts have been developed for water splitting [3-12], $\mathrm{CO}_{2}$ reduction [13$21]$, and $\mathrm{O}_{2}$ reduction $[22,23]$. However, the molecular catalysts in homogeneous solution often suffer from low stability in redox conditions. In addition, debates have been made whether the organometallic catalysts are true homogeneous catalysts or just a precursor of heterogeneous catalysis [24]. One important implication of natural photosynthetic system is that the molecular cofactors are optimally positioned in a protein matrix, so the photochemical processes are carried out in an efficient and robust way [25-28]. Although replicating the complicated configuration of natural photosystem is not that straightforward, more simple chemistry was addressed to immobilize molecular catalysts in solid matrices, i.e., covalent bonds and non-covalent interactions. This review revisits the techniques for immobilizing molecules in solid supports and summarizes recent advances in artificial photosynthesis using the techniques. 


\section{Immobilization methods}

\subsection{Covalent immobilization}

Covalent bond between a catalyst and its support can result in stable immobilization. Several synthetic methods have been proposed for covalent attachment of molecular catalysts onto carbon-based surfaces [29-32]. A widely used strategy to for direct $\mathrm{C}-\mathrm{C}$ bond formation was pioneered by Pinson and Savéant is based on electrochemical grafting based on reduction of aryl diazonium molecules. The diazonium salts are reduced on the surface of carbon-based electrode to form aryl radicals, which reacts with the carbon surface to form stable $\mathrm{C}-\mathrm{C}$ bonds [31-33]. This method was successfully adopted for the preparation of quinone decorated electrodes showing electrocatalytic activities for catalytic oxygen reduction (Scheme 1a) [34-39].

An alternative approach based on electrochemical oxidation of aryl acetates was reported [40-42]. The detailed mechanism is more complicated compared to the diazonium pathway and still under debate [42, 43]. González group proposed one possible mechanism, where anodic oxidation of carboxylates results in removal of $\mathrm{CO}_{2}$, thus yields arylmethyl radical. The radical can be further oxidized to form methyl carbocation, which forms $\mathrm{C}-\mathrm{C}$ bond with carbon surface (Scheme 1b) [42].

Pre-functionalization of carbon materials provides synthetic feasibility to incorporate molecular catalysts. Oxidation of carbon surface provides oxygen-containing groups, such as ketone, quinone, phenol, lactone, carboxyl group, ether, acid anhydride, ketene, etc. [44], which can serve as anchoring sites for subsequent functionalization with molecular catalysts (Fig. 1a). More recently, fluorinated graphene (FG) has been shown to be susceptible to nucleophilic substitution to form sulfhydryl [45], amino [46-49], dichlorocarbene [50], or urea [51] groups for further functionalization (Fig. 1b). Regarding the chemical structure of FG, it has been considered as chemically inert material as an analogue to polytetrafluoroethylene $\left(\right.$ Teflon $^{\circledR}$ ) [52]. However, after Zbořil group reported reductive defluorination of FG [53], a number of methods have been developed for modification of FGs [54].

Another example is the $\mathrm{Cu}^{\mathrm{I}}$-catalyzed azide-alkyne cycloaddition (CuAAC) "click" reaction. The click reaction usually uses mild reaction condition and gives high conversion yield. Azide-modification of graphitic carbon surface can be simply carried out by either immersing them in acetonitrile solution of $\mathrm{IN}_{3}$ or exposing them to $\mathrm{IN}_{3}$ gas [55-57]. Further modification of carbon surface then can be carried out with $\mathrm{CuAAC}$ reaction (Scheme 2).

Metal-organic frameworks (MOFs) are emerging platforms for immobilization of molecular catalysts. Development of synthetic strategies of metal-organic frameworks (MOFs) provides rational design of molecular catalysts embedded in them. Two major constitutional components of MOF are metal ions/clusters and linking ligands, providing strategies to realize MOF catalysis based on (i) metal ions/clusters as catalytic sites or (ii) modification of organic ligands with molecular catalysts, respectively [58].

\subsection{Non-covalent immobilization}

Non-covalent immobilization of molecular catalysts allows a facile mix-and-go strategy for catalyst preparation $[59,60]$. A figure of merit for non-covalent interaction over covalent bonding is that due to the rather weak electronic interplay, the physical/chemical properties of

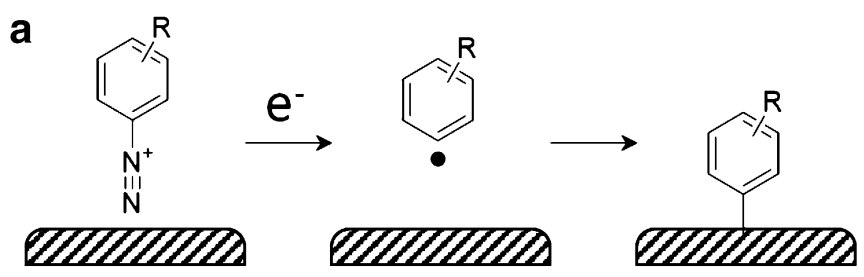

b

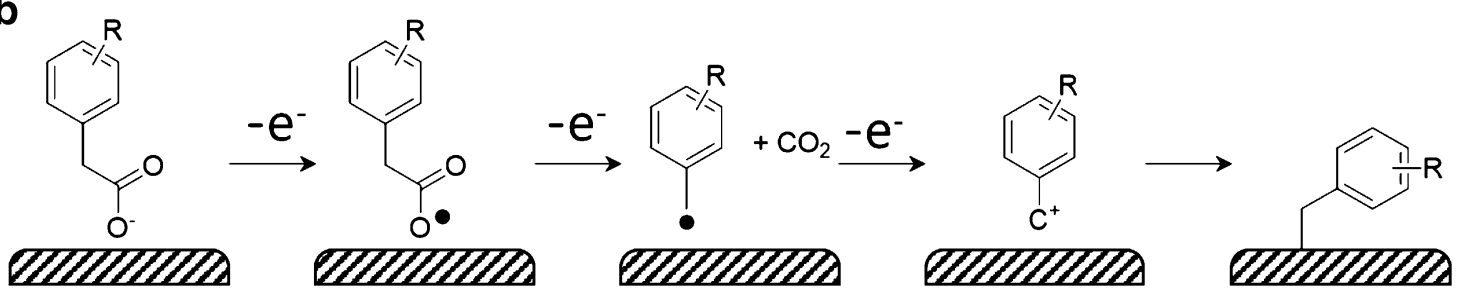

Scheme 1 Covalent attachment of $\mathbf{a}$ aryl diazonium salts and $\mathbf{b}$ aryl acetates onto carbon surface 


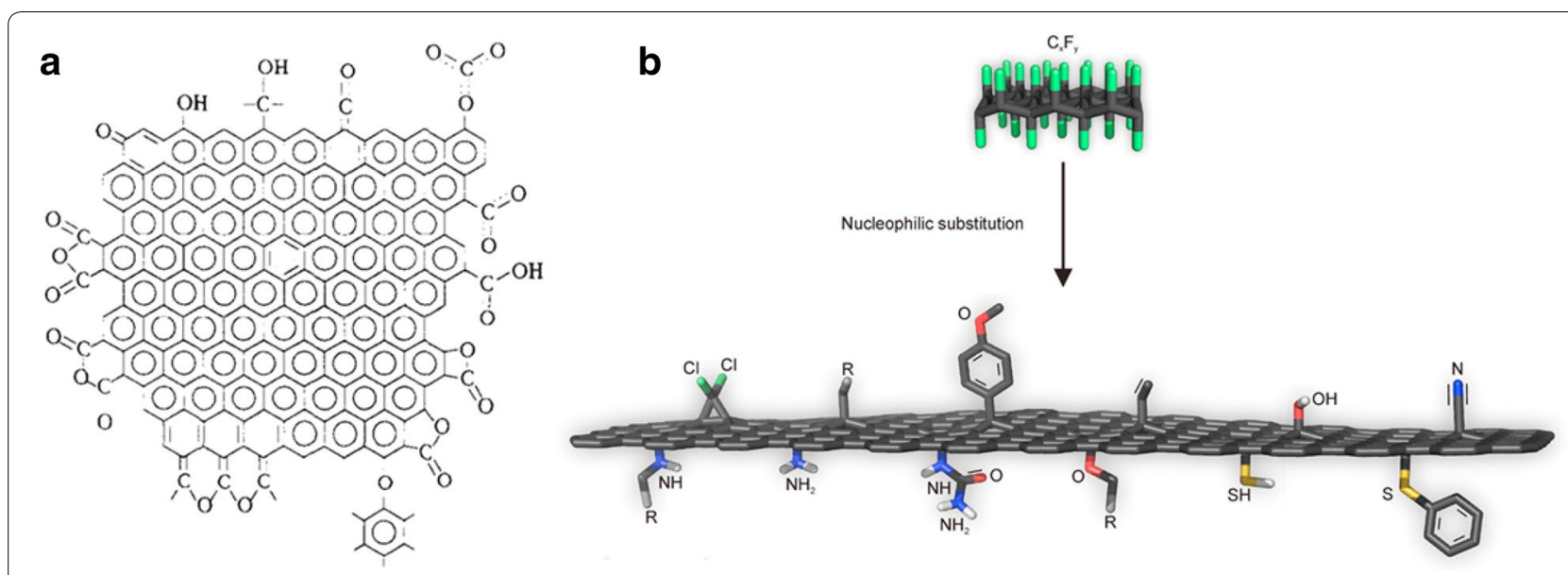

Fig. 1 a Oxidative functionalization of carbon surfaces. Reproduced from [44] with copyright permission from 1993 Elsevier Ltd. b Preparation of graphene derivatives from fluorographene. Reproduced from [54] with copyright permission from 2017 Elsevier Ltd.

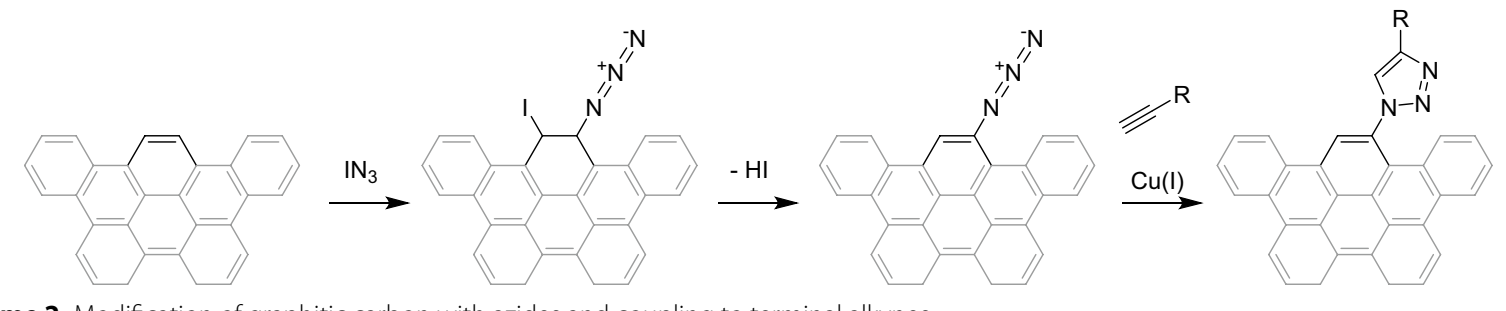

Scheme 2 Modification of graphitic carbon with azides and coupling to terminal alkynes

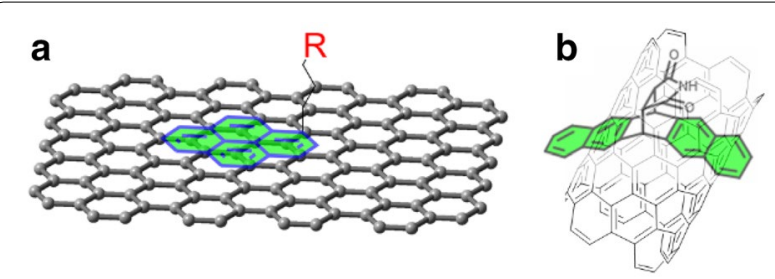

Fig. 2 Schematic representation of a pyrenyl moiety sitting on the basal plane of graphene (a) and a Diels-Alder adduct of pentacene tweezing a single-walled carbon nanotube (b) through $\pi-\pi$ interaction

both anchoring molecules and supporting matrices can be maintained. A number of non-covalent functionalization strategies, using $\pi-\pi$ interaction, hydrogen bonding, electrostatic interaction, physical encapsulation, and mechanical interlocking, etc., have been reported so far.

Extended aromatic moieties such as pyrenyl group has been widely explored for immobilization of molecules on graphitic carbons based on the strong $\pi-\pi$ interaction between them (Fig. 2a) [61-65]. Especially, a Diels-Alder adduct of pentacene has optimal dimension with the curvature of single-wall carbon nanotubes (CNTs), thus forms tweezer-like binding (Fig. 2b) [66]. The size-specific interaction enabled separation of CNTs mixture in 1-2 nm diameter range. For graphene oxide (GO), additional hydrogen-bond with epoxides, alcohols, ethers, and carboxylic acids can be formed in addition to the $\pi-\pi$ interaction. The strong interaction of aromatic moieties with graphitic carbons was further evidenced by microscopic techniques [67-71].

Electrostatic interaction can also play a role to immobilize molecular catalysts. Oxidized CNTs or graphenes can afford strong ionic conjugates. Liang et al. demonstrated functionalization of GO and reduced graphene oxide (rGO) with ammonium salts [72]. Electrostatic functionalization of carbon support can be further expanded to end-functional polymers. Kim group reported stable dispersion of rGO in organic solvents by incorporating amine-terminated polystyrene [73]. Hydrophobicity/hydrophilicity of a molecule-support hybrid system can be effectively tuned by this technique, thus opens wider range of solvent selection. 


\section{Photocatalysis}

Photocatalysis is a process where light energy is directly converted into chemical energy. It starts with absorption of photons by photosensitizers, followed by cascade charge/energy transfer to catalysts which convert substrates into products. Artificial photosynthesis schemes are multi-electronic processes, which implies multiple charges should be directed and accumulated at the catalytic center to run the photochemical cycles (Scheme 3a). It is a challenging subject, since photon absorption is generally a monoelectronic process, results in single charge production. In this context, it is required to accumulate electron/holes by multiple rounds of single electronic absorption before exciton decay, charge recombination, or back charge transfer. The best example is photosystem II (PSII) in chlorophyll, which is responsible for $\mathrm{O}_{2}$ evolution in natural photosynthesis. The active units in PSII are optimally positioned in a protein matrix so the charge transfer reactions are kinetically controlled to extract four electrons from a $\mathrm{Mn}_{4} \mathrm{Ca}$ cluster to run water oxidation (Scheme 3b) [74]. It is not straightforward to directly replicate the complex protein matrix of nature, however, efforts have been made to borrow the strategies in more simple chemical bonds or supramolecular chemistry [75-79].

\subsection{MOFs as immobilizing matrices}

Many MOFs bearing aromatic ligands have broad UVvis absorption assigned to metal-to-ligand charge transfer (MLCT), ligand-to-metal charge transfer (LMCT), or ligand-centered (LC) $\pi-\pi^{*}$ transition. This feature inspired researchers to use them as immobilizing matrices for molecular photosensitizers/catalyst for various photocatalytic reactions such as degradation [80-85] or transformation [86-89] of organic molecules, and organic photocatalysis.

Ni-based MOFs are reported as visible-light driven photocatalysts for $\mathrm{CO}_{2}$ reduction. Simple ligand modification for PCN-222 and PCN-601 resulted in major products of formate anion and $\mathrm{CH}_{4}$, respectively [90, 91]. The result implies the importance of ligand selection, which affects the charge separation/transfer kinetics and the reaction sphere morphology. Li group introduced amino groups into the bridging ligands, resulting in increased catalytic activities for $\mathrm{CO}_{2}$ reduction compared to the MOFs without amino groups [92, 93]. Systematic studies on Ti-based MOFs, namely MIL-125(Ti) for amine-free MOF and $\mathrm{NH}_{2}$-MIL-125(Ti) for aminofunctionalized MOF, showed the amine moiety on the ligands enhances light absorption in the visible range and increases adsorption of $\mathrm{CO}_{2}$ (Fig. 3).

Photocatalytic activities can be further enhanced by incorporating photosensitizers and/or catalysts into the MOFs. The UiO MOFs have been extensively studied as immobilizing matrix for molecular catalysts due to their facile ligand tunability and high chemical/photochemical stabilities. The UiO family has a configuration where $\mathrm{Zr}_{6}(\mathrm{OH})_{4} \mathrm{O}_{4}{ }^{12+}$ clusters are 12 -connected by organic dicarboxylate linkers to form a MOF framework with fcc structure. Various organometallic complexes can replace the linking ligands by filling the well-defined cavities while maintaining the structure of parent $\mathrm{UiO}$ MOF.

Lin group reported a UiO-67 $\left(\mathrm{Zr}_{6} \mathrm{O}_{4}(\mathrm{OH})_{4}(\mathrm{bpdc})_{6}\right.$, where bpdc is $p$-biphenyldicarboxylic acid) based MOF

\section{a Water Splitting}

$$
\begin{array}{ll}
\begin{array}{ll}
2 \mathrm{H}_{2} \mathrm{O} \\
4 \mathrm{H}^{+}+4 \mathrm{e}
\end{array} & 4 \mathrm{e}+4 \mathrm{H}^{+}+\mathrm{O}_{2} \\
\text { Oxygen Reduction } & 2 \mathrm{H}_{2}
\end{array}
$$

\section{Oxygen Reduction}

$$
\begin{array}{rll}
\mathrm{O}_{2}+2 \mathrm{H}^{+}+2 \mathrm{e} & \longrightarrow \mathrm{H}_{2} \mathrm{O}_{2} \\
\mathrm{O}_{2}+4 \mathrm{H}^{+}+4 \mathrm{e} & \longrightarrow & 2 \mathrm{H}_{2} \mathrm{O} \\
\mathrm{CO}_{2} \text { reduction } & & \\
\mathrm{CO}_{2}+2 \mathrm{H}^{+}+2 \mathrm{e} & \longrightarrow \mathrm{CO}+2 \mathrm{H}_{2} \mathrm{O} \\
\mathrm{CO}_{2}+6 \mathrm{H}^{+}+6 \mathrm{e} & \longrightarrow \mathrm{CH}_{3} \mathrm{OH}+\mathrm{H}_{2} \mathrm{O} \\
\mathrm{CO}_{2}+8 \mathrm{H}^{+}+8 \mathrm{e} & \longrightarrow \mathrm{CH}_{4}+2 \mathrm{H}_{2} \mathrm{O}
\end{array}
$$

b

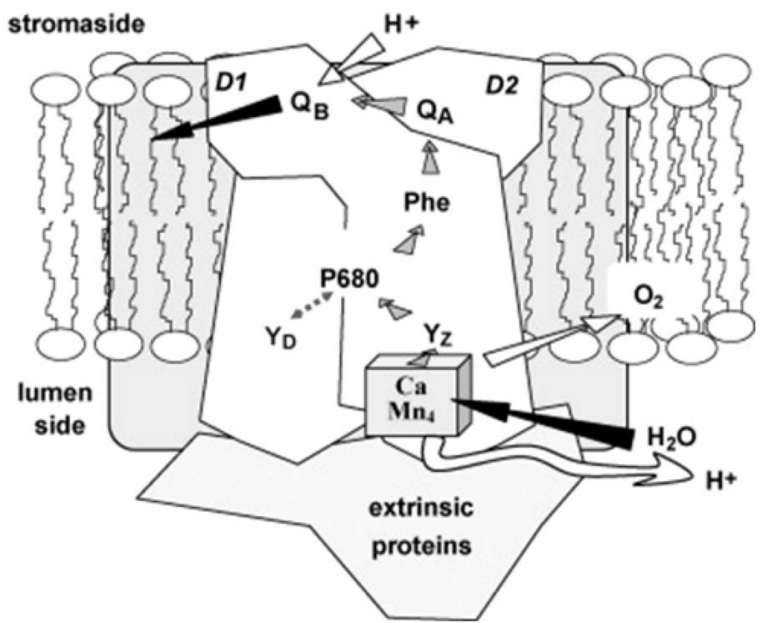

Scheme 3 a Electron equivalents of various artificial photosynthetic processes. b Arrangement of subunits in PSII. Copyright permission from Elsevier [74] 

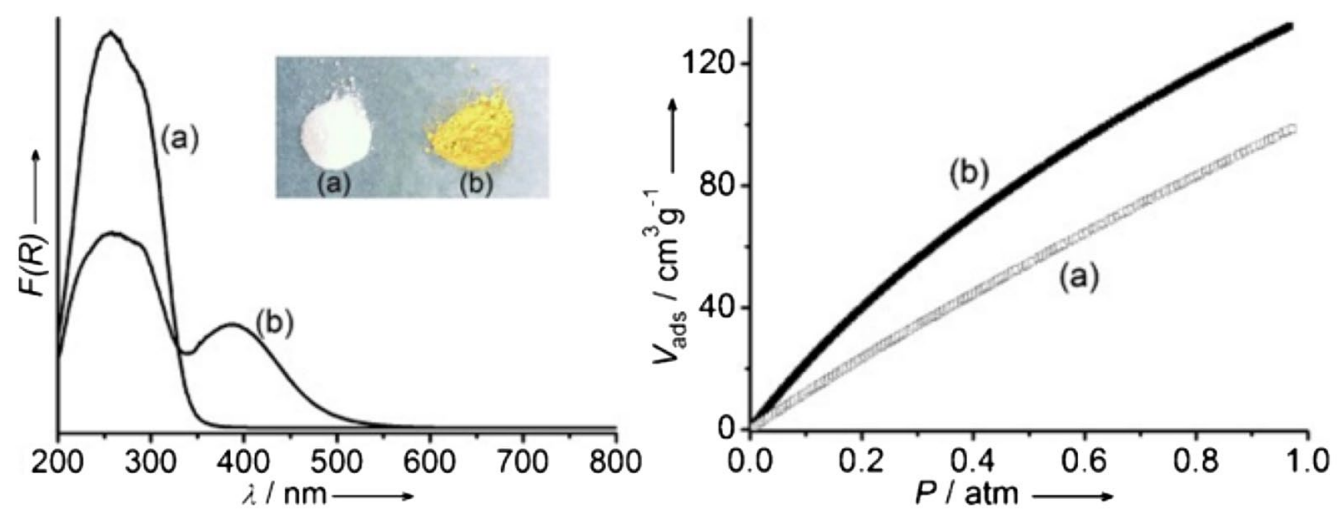

Fig. 3 UV-vis absorption (left) and $\mathrm{CO}_{2}$ adsorption isotherms (1 atm, $273 \mathrm{~K}$, right) of $\mathbf{M I L - 1 2 5}$ (Ti) and $\mathbf{N H}_{\mathbf{2}}$ - $\mathbf{M I L}-\mathbf{1 2 5}$ (Ti). The inset photo shows absorption colors. Copyright permission from Wiley-VCH [93]

containing catalytically active $\operatorname{Ir}(\mathrm{III}), \operatorname{Re}(\mathrm{I})$, or $\operatorname{Ru}(\mathrm{II})$ complexes [94]. The MOFs were synthesized through mix-and-match strategy, owing to the matching ligand lengths between bpdc and metal-functionalized ligands (Fig. 4). MOFs 1-3 containing $\mathrm{Cp} * \mathrm{Ir}(\mathrm{III})(\mathrm{dcppy}) \mathrm{Cl}$ (where $\mathrm{Cp}^{*}$ is pentamethylcyclopentadienyl and dcppy is 2-phenylpyridine-5,4'-dicarboxylic acid) or $\operatorname{Ir}(\mathrm{III})$ (dcppy) ${ }_{2}\left(\mathrm{H}_{2} \mathrm{O}\right)_{2}$ were effective water oxidation catalyst with tyrnover frequencies up to $4.8 \mathrm{~h}^{-1}$. The $\operatorname{Re}(\mathrm{I})$ $(\mathrm{CO})_{3}(\mathrm{dcbpy}) \mathrm{Cl}\left(\mathrm{H}_{2} \mathbf{L}_{4}\right.$, where dcbpy is $2,2^{\prime}$-bipyridyl-5,5'dicarboxylic acid) derivatized MOF $\mathbf{4}$ served as an active catalyst for photocatalytic $\mathrm{CO}_{2}$ reduction with a total turnover number of 10.9, three times higher than that of the homogeneous complex $\mathrm{H}_{2} \mathbf{L}_{4}$.
Kim et al. selected a bipyridine-embedded UiO-67 MOF, namely $\mathrm{BUiO}$, as a self-healing platform for molecular $\mathrm{Pt}(\mathrm{II})$ catalysts and $\operatorname{Ir}(\mathrm{III})$ photosensitizers. A series of BUiO-based MOFs, namely, $\mathbf{P t}_{\mathbf{n}-} \mathbf{I r} \_\mathbf{B U i O}$, comprising 2,2'-bipyridine-5,5'-dicarboxylate $(\mathbf{L})$ as a self-healing site, $\mathrm{Pt}(\mathrm{II})(\mathbf{L}) \mathrm{Cl}_{2}$ as a $\mathrm{H}_{2}$-evolving catalyst, and $\mathrm{Ir}(\mathrm{III})$ $(\text { ppy })_{2}(\mathbf{L})$ as a photosensitizer were synthesized and tested for photocatalytic $\mathrm{H}_{2}$ production [95]. When the metal-diimine bonds were cleaved during photolysis, abundant free diamine ligands promoted re-coordination of the cleaved metal ions to recover the molecular catalytic activity (Fig. 5a). Accordingly, the catalysis with $\mathbf{P t}_{\mathbf{0 . 1} \_} \mathbf{I r}$ _BUiO prolonged more than 6.5 days without significant decrease in its activity, while the control MOF a<smiles>O=C(O)c1ccc(-c2ccc(Nc3ccccc3)cc2)cc1</smiles>

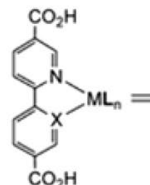

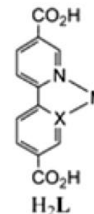

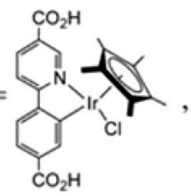

$\mathrm{H}_{2} \mathbf{L}_{1}$ $\mathrm{CO}_{2} \mathrm{H}$

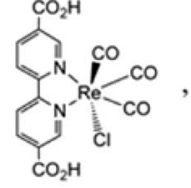

$\mathrm{H}_{2} \mathbf{L}_{4}$
$\left.\frac{\mathrm{DMF}}{100^{\circ} \mathrm{C}} \mid \mathrm{Zr}_{6}\left(\mu_{3}-\mathrm{O}\right)_{4}\left(\mu_{3}-\mathrm{OH}\right)_{4}(\mathrm{bpdc})_{8-x}(\mathbf{L})_{x}\right]$

Ir/Re/Ru doped UiO-67 (MOFs 1-6 for $L_{1}-L_{6}$ )

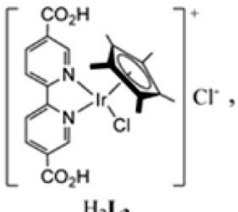
$\mathrm{H}_{2} \mathbf{L}_{2}$
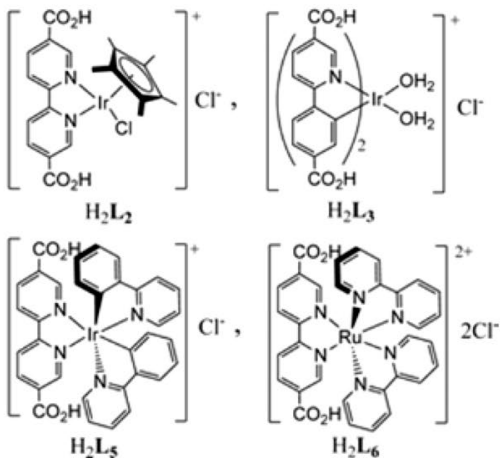

b

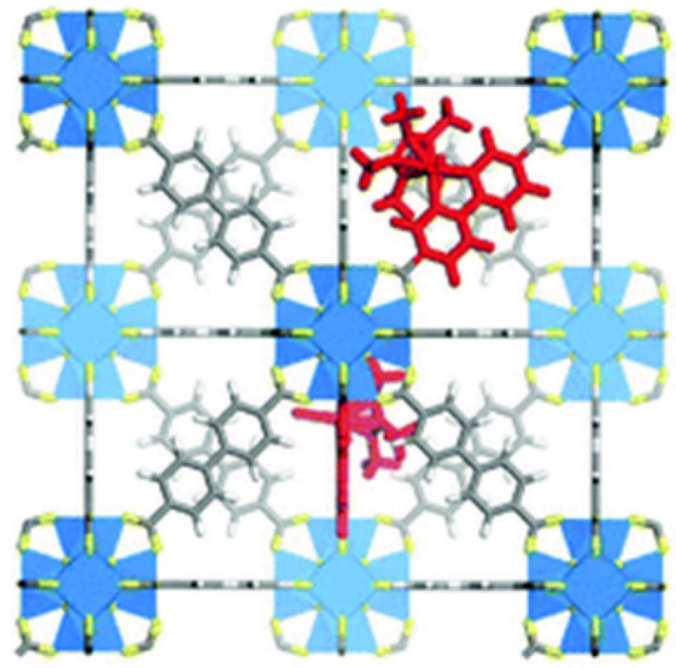

Fig. 4 a Synthesis of organometallic catalysts doped UiO-67. b Structure of L1-doped UiO-67. The inset photo shows absorption colors. Copyright permission from ACS. [94] 


\section{a}

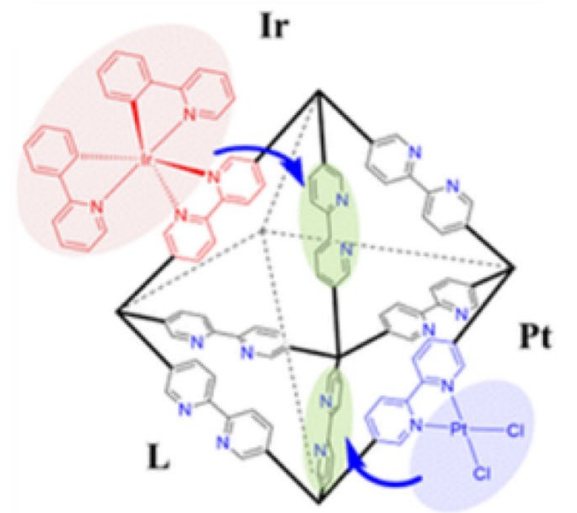

$\mathrm{Pt}_{\mathrm{n} \_} \mathrm{Ir}_{-}$BUiO

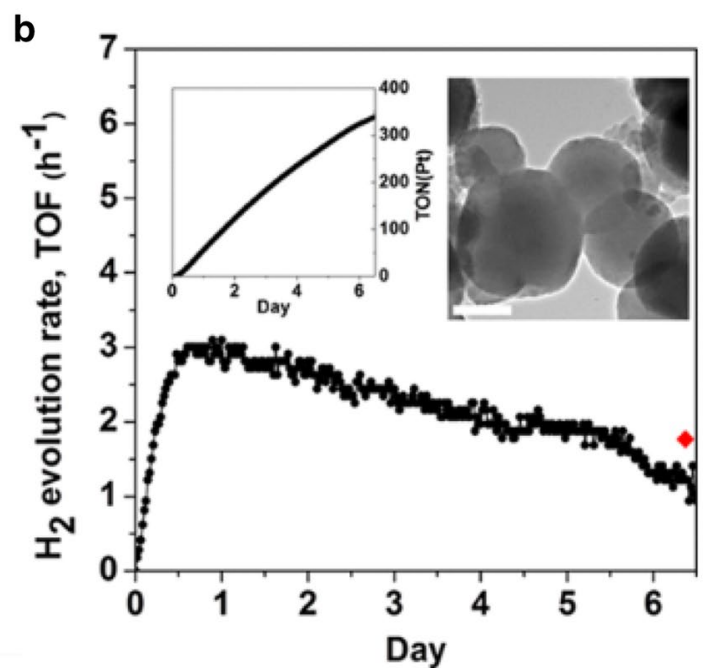

Fig. 5 a Schematic operation principle of self-healing MOF ( $\left.\mathbf{P t}_{\mathbf{n} \_} \_\mathbf{I r} \_\mathbf{B U i O}\right) . \mathbf{b} \mathrm{H}_{2}$ evolution rate curve of $\mathbf{P t}_{\mathbf{0 . 1}} \_\mathbf{I r} \_\mathbf{B U i O}$. Inset: total amount of $\mathrm{H} 2$ evolved (left) and HR-TEM image after 6.5 days of photolysis. Scale bar $=200 \mathrm{~nm}$. Copyright permission from ACS [95]

without a free diimine ligand lost molecular catalytic activity after $7.5 \mathrm{~h}$ by leaching of Pt and forming colloids (Fig. 5b).

\subsection{Dye-sensitized inorganic/organometallic hybrids}

In inorganic photocatalysis, metal oxides are typically studied due to their stability and facile synthesis. More importantly, multiple charges can be stored in a nanocrystal, which can be further utilized for multielectronic photocatalytic cycles. Depending on the size of a nanocrystal, different maximum number of charges can be stored. Mayer and co-workers have shown a $\mathrm{ZnO}$ nanocrystal with $3.5 \mathrm{~nm}$ radius can take up to 120 electrons per particle [96]. Most of them work well with UV light and only a few visible-light-responsive photocatalytic systems are reported so far $[97,98]$. Non-oxide nanocrystals such as CdS or CdSe have suitable bandgaps with strong visible-light absorption, which is suitable for artificial photosynthesis. However, the toxicity of Cd limits their usage in real life. As an analogue to dye-sensitized solar cells, hybridizing inorganic nanocrystals with organic/organometallic dyes offers visible-light driven photocatalysis. Scheme 4 illustrates electronic processes in a $\mathrm{Ru}(\mathrm{II})-\mathrm{TiO}_{2} / \mathrm{Pt}$ system for photocatalytic $\mathrm{H}_{2}$ production: photoexcitation of a $\mathbf{R u}(\mathrm{II})$ photosensitizer $\left(\mathbf{R} \mathbf{u}^{\mathrm{II}} \mathbf{L}_{\mathbf{x}}\right)$, followed by (1) charge transfer from the photoexcited states of the $\mathrm{Ru}(\mathrm{II})$ dye $\left(\mathbf{R} \mathbf{u}^{\mathrm{II}{ }^{*}} \mathbf{L}_{\mathbf{x}}\right)$ to $\mathrm{TiO}_{2}$ nanocrystal, (ii) back electron transfer from $\mathrm{TiO}_{2}$ conduction band to the dye, (iii) electron transfer to Pt catalyst, (iv) water reduction to produce $\mathrm{H}_{2}$, and (v) regeneration of the $\mathbf{R u}^{\mathrm{II}} \mathbf{L}_{\mathbf{x}}$ ground state by an electron donor $(\mathbf{D})$.

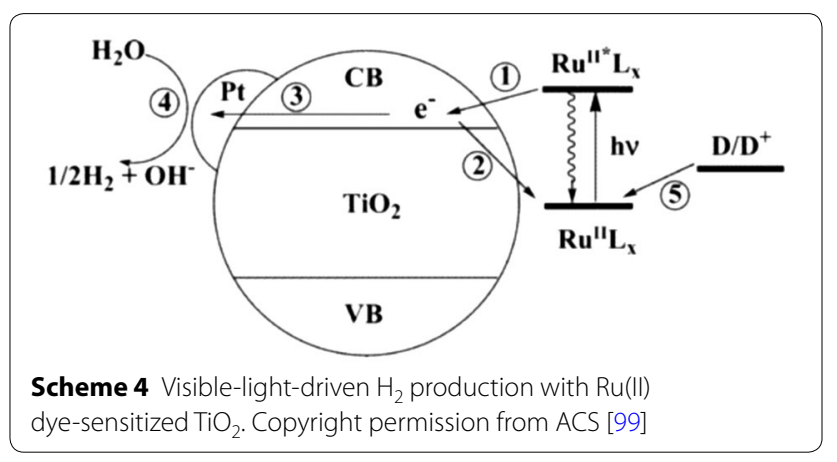

Kaneko and co-workers reported sensitization of $\mathrm{TiO}_{2} /$ $\mathrm{Pt}$ nanoparticles with $\mathrm{Ru}(\mathrm{II})$ dyes for visible-light driven $\mathrm{H}_{2}$ evolution from water [100]. The study shows the importance of anchoring groups: $\mathrm{Ru}(\mathrm{II})(\mathrm{bpym}){ }_{3}{ }^{2+}$ (where bpym is bipyrimidine) showed much higher $\mathrm{H}_{2}$ evolution rate $\left(80.1 \mu \mathrm{l} \mathrm{h}{ }^{-1}\right)$ than $\mathrm{Ru}(\mathrm{dcbpy})_{3}{ }^{4-}\left(17.8 \mu \mathrm{l} \mathrm{h}^{-1}\right)$ or $\mathrm{Ru}(\mathrm{bpy})_{3}{ }^{2+}\left(23.3 \mu \mathrm{l} \mathrm{h}^{-1}\right)$. Further investigation has been made on $\mathrm{Ru}(\mathrm{II})$-sensitized $\mathrm{TiO}_{2} / \mathrm{Pt}$ to find structure-catalytic activity relationships for photocatalytic $\mathrm{H}_{2}$ production from water [99, 101-103].

Noble metal-free dye-sensitized systems have been also investigated. Yuan et al.. reported a noble metal-free $\mathrm{H}_{2}$ production system with $\mathrm{Zn}$ porphyrin sensitized $\mathrm{MoS}_{2} /$ $\mathrm{ZnO}$ [104]. The $0.50 \mathrm{wt} \% \mathrm{ZnTCPP}-\mathrm{MoS}_{2} / \mathrm{ZnO}$ (where TCPP is 5,10,15,20-tetrakis(4-carboxyphenyl)-porphyrin) photocatalyst showed $\mathrm{H}_{2}$ evolution rate of $75 \mu \mathrm{mol} \mathrm{h}{ }^{-1}$ $\mathrm{g}^{-1}$, which is comparable with the $\mathrm{Ru}(\mathrm{II})-\mathrm{TiO}_{2} / \mathrm{Pt}$ photocatalysts. $\mathrm{Li}$ and co-workers reported a 5,10,15,20-tetraphenylporphyrin- $-\mathrm{Cu}_{2} \mathrm{O}$ photocatalyst with $\mathrm{H}_{2}$ evolving rate of $1.3 \mathrm{mmol} \mathrm{g}^{-1}$. 


\subsection{Modification of carbon materials}

Yang and co-workers reported a 5,10,15,20-tetrakis(4(hydroxyl)phenyl) porphyrin (TPPH) non-covalently adsorbed on rGO with Pt nanoparticles [105]. Strong $\pi-\pi$ interaction between TPPH and rGO offers stable photocatalysis (Scheme 5a). The TPPH-RGO/Pt catalyst showed an effective photocatalytic activity with a $\mathrm{H}_{2}$ production rate of $5.29 \mathrm{mmol} \mathrm{g}^{-1}$. Li and co-workers reported $\mathrm{Cr}^{3+}$ implemented GOs bridged by 5,15-diphenyl-10,20-di(4-pyridyl)porphyrin (DPyP) [106]. Instead of forming $\pi-\pi$ stacking between DPyP and GO, DPyP molecules are oriented to the out-ofplane direction of GO sheets by means of electrostatic and coordination interactions (I and II in Scheme 5b). The DPyP-Cr ${ }^{3+}-\mathrm{GO}$ showed visible-light-driven $\mathrm{H}_{2}$ production with activities of $928 \mu \mathrm{mol} \mathrm{g}^{-1}$, while the control DPyP-GO (III in Scheme 5b) showed that of $686 \mu \mathrm{mol} \mathrm{g}^{-1}$.

\section{Dye-sensitized photoelectrochemical (DS-PEC) cells}

In the early 1970s, Honda and Fujishima reported a photoelectrochemical (PEC) water splitting cell comprising $\mathrm{TiO}_{2}$ photoanode and Pt counter electrode (Fig. 6) [107, 108]. By illumination of the photoanode $(\lambda<415 \mathrm{~nm})$, $\mathrm{O}_{2}$ and $\mathrm{H}_{2}$ were generated at the photoanode and counter electrode, respectively. Since the pioneering works by Honda and Fujishima, significant progress has been made in pursuit of $\mathrm{PEC}$ water splitting systems using $\mathrm{TiO}_{2}$ photoanode or $\mathrm{NiO}$ photocathode. However, the large bandgaps of $\mathrm{TiO}_{2}$ and $\mathrm{NiO}$ limits the PEC cells operating with visible light. To tackle this issue, visible-light-absorbing semiconductors (VLA-SCs) have been studied, however, the catalytic activities of the VLA-SCs are rather lower than those of $\mathrm{TiO}_{2}$ or $\mathrm{NiO}[109,110]$.

One promising strategy is sensitizing the large bandgap inorganic semiconductors with molecular photosensitizers. The concept of dye-sensitized solar cell (DSSC) was first proposed by O'Regan and Grätzel in 1991 [111]. $\mathrm{Ru}$ (II) complexes were adsorbed on the surface of $\mathrm{TiO}_{2}$
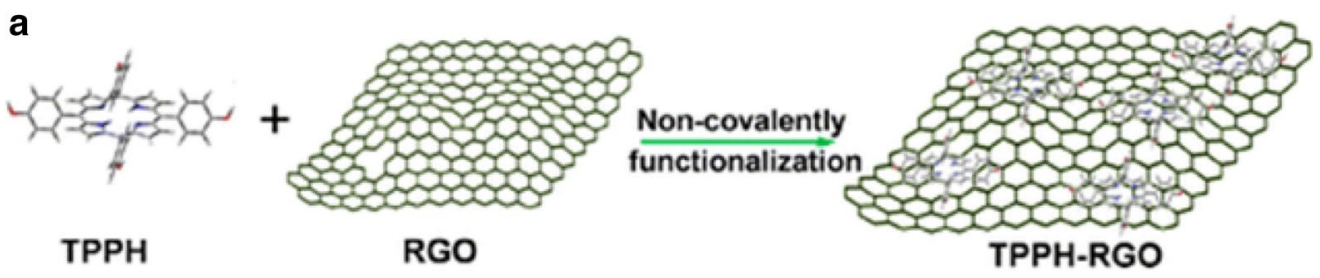

b

GO
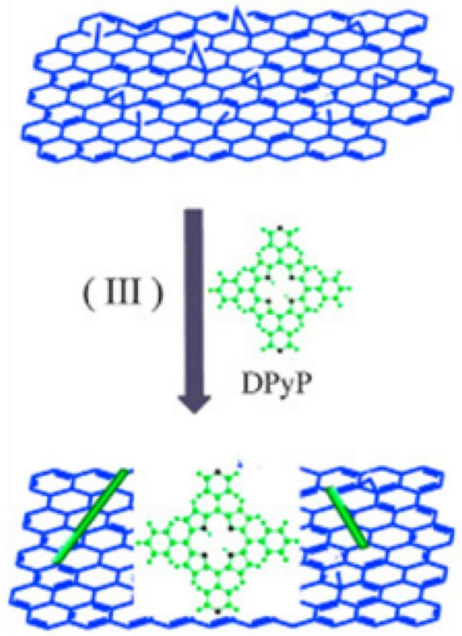

GO-DPyP

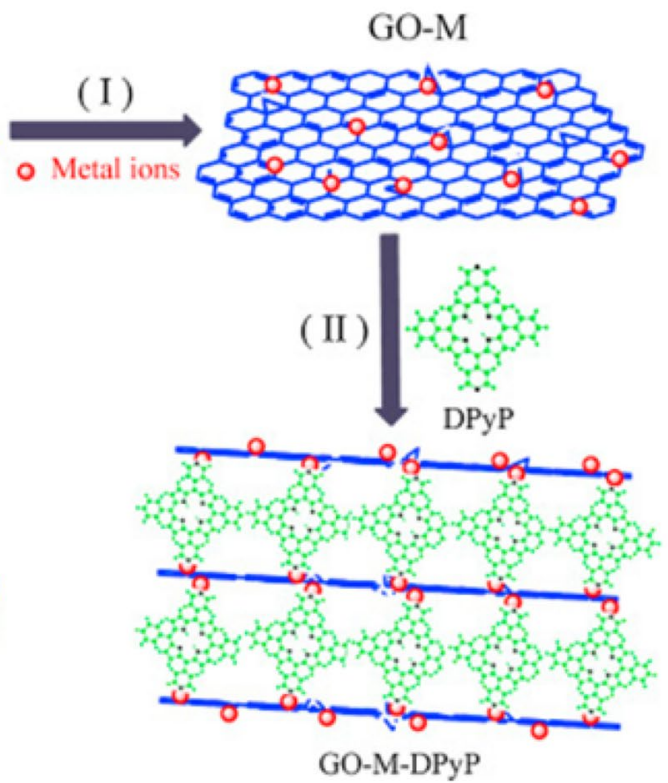

Scheme 5 a lllustration of non-covalent incorporation of TPPH on the basal plane of rGO surfaces through Strong $\pi-\pi$ interaction. $\mathbf{b}$ Formation of DPyP-Cr ${ }^{3+}-\mathrm{GO}(\mathrm{I}$ and II) and DPyP-GO. Copyright permissions from ACS $[105,106]$ 


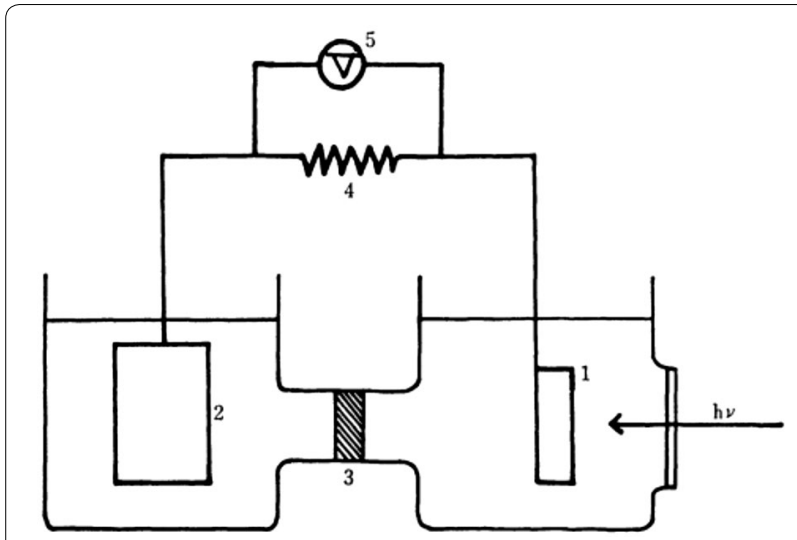

Fig. 6 Illustration of a PEC cell reported by Honda and Fujishima: 1 is a $\mathrm{TiO}_{2}$ photoanode, $\mathbf{2}$ is a Pt counter electrode, $\mathbf{3}$ is a sintered glass diaphragm, $\mathbf{4}$ is an external load, and $\mathbf{5}$ is a voltameter. Copyright permission from The Chemical Society of Japan [107]

nanocrystals, which facilitates visible-light absorption by the $\mathrm{Ru}(\mathrm{II})$ dyes, followed by electrons from the photoexcited states injected into the $\mathrm{TiO}_{2}$ nanocrystals. The DSSC was first designed to generate electricity; same strategy can be applied to DS-PEC cells for catalytic reactions. Figure 5 depicts the working principle of a water splitting DS-PEC with dye-sensitized photoanode: (i) light absorption by dyes anchored to $\mathrm{n}$-type semiconductor nanoparticles, (ii) injection of photoexcited electrons into the conduction band of semiconductor, (iii) extraction of electrons from water oxidation catalysts (WOCs), (iv) flow of electrons to counter electrode of Pt through outer circuit, and (v) catalysis on the surface of each electordes with supplied holes/electrons (Scheme 6). As an analogue to the dye-sensitized photoanode, dye-sensitized photocathode is also feasible, by incorporating dyes with p-type semiconductor nanoparticles.

Mallouk and co-workers first reported a visible-lightdriven water splitting DS-PEC cell [113]. Ru(II) dyes bridge $\mathrm{TiO}_{2}$ nanoparticles and $\mathrm{IrO}_{2} \cdot \mathrm{nH}_{2} \mathrm{O}$ nanoparticles, directing cascade electron/hole transfer between them (Fig. 7a). Low internal quantum yield of $0.9 \%$ was reported due to: (i) slow electron transfer between $\mathrm{IrO}_{2} \cdot \mathrm{nH}_{2} \mathrm{O}$ and oxidized $\mathrm{Ru}(\mathrm{II})$ dye and (ii) back electron transfer from $\mathrm{TiO}_{2}$ to the dye. To overcome the inefficient charge interplays, an electron mediator was incorporated to the photoanode, resulting in an increased internal quantum efficiency to $2.3 \%$. Inspired by the works by Maooluk group, a number of dye-sensitized photoanodes for water splitting DS-PEC cells have been reported [114-127].

Reductive catalysis such as $\mathrm{CO}_{2}$ reduction or $\mathrm{O}_{2}$ reduction requires development of photocathodes with proper catalysts assembly. Inoue and co-workers reported a

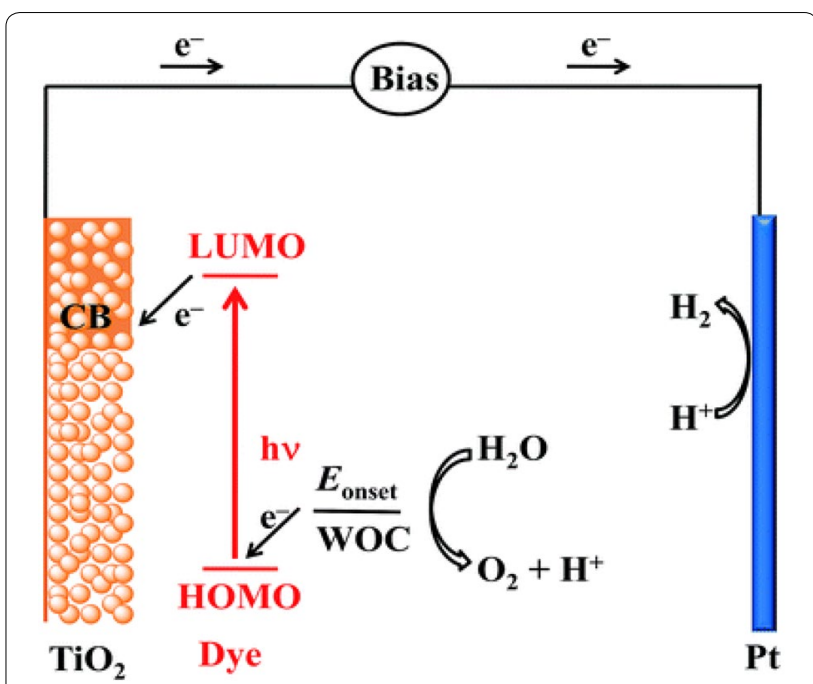

Scheme 6 Schematic working principles of a water splitting DS-PEC with dye-sensitized DS-PEC cell. Copyright permission from RSC [112]

reduction of $\mathrm{CO}_{2}$ with dye-sensitized photocathode where a dinuclear $\mathrm{Zn}(\mathrm{II})-\operatorname{Re}(\mathrm{I})$ complex is anchored to the surface of $\mathrm{NiO}$ nanoparticles (Fig. 7b) [128]. Although

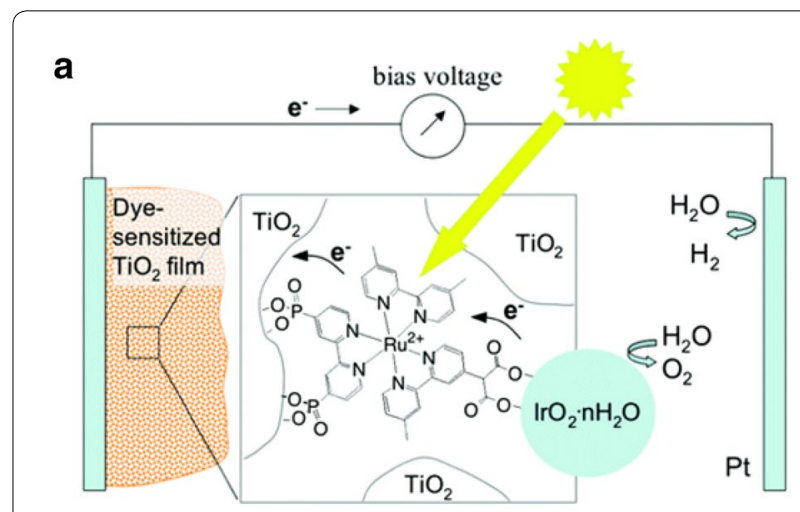

b

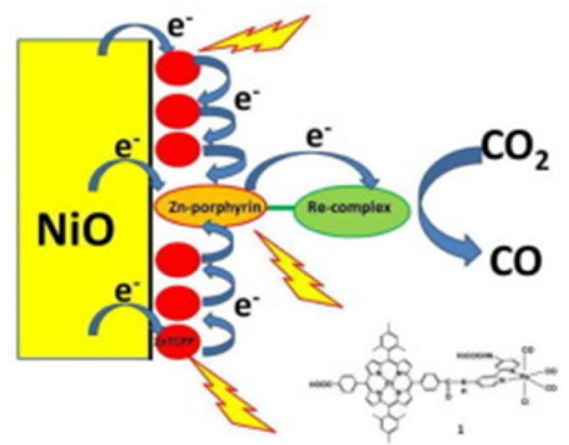

Fig. 7 DS-PEC cells with a a dye-sensitized photoanode for water splitting and $\mathbf{b}$ a dye-sensitized photocathode for $\mathrm{CO}_{2}$ reduction. Copyright permissions from ACS and Elsevier [113, 128] 
a<smiles>CN1C(=O)C(=O)N2C(=O)C(=O)N3C(=O)N(C)C123</smiles>

$[(\mathrm{L}) \mathrm{Cu}]^{2 \cdot}\left(1^{2 \cdot}\right)$

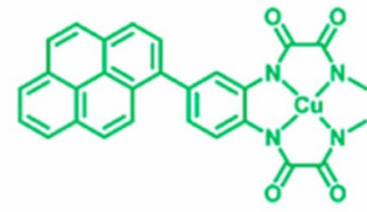

$\left[\left(L_{\text {py }}\right) \mathrm{Cu}\right]^{2 \cdot} \cdot\left(\mathbf{2}^{2 \cdot}\right)$

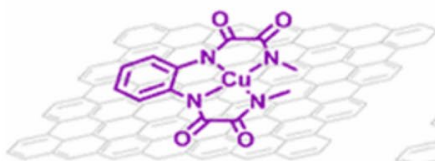

GC@G@[(L)Cu $]^{2 \cdot}\left(G-1^{2} \cdot\right)$

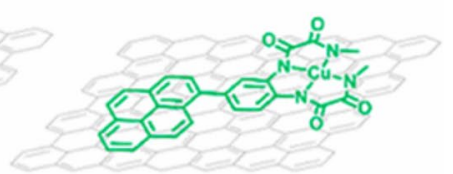

$G C @ G @\left[\left(L_{p y}\right) C u\right]^{2 \cdot} \cdot\left(G-2^{2} \cdot\right)$ b
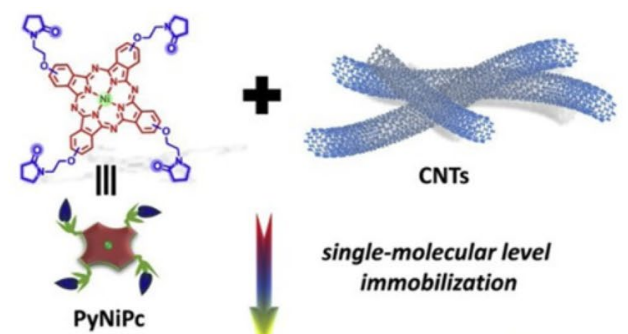

single-molecular level immobilization

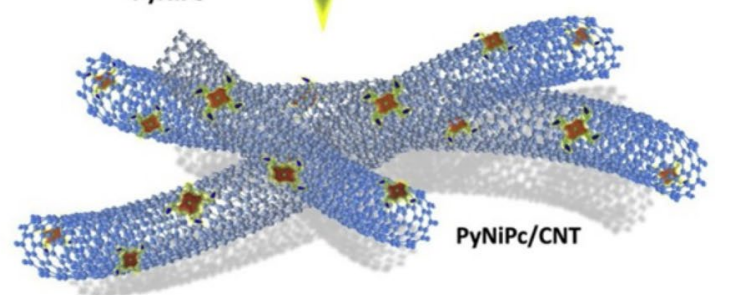

Fig. 8 Adsorption of molecular catalysts on a the basal plane of graphene and $\mathbf{b}$ CNTs. Copyright permissions from Elsevier and ACS [133, 135]

efficient hole injection efficiency from the dye to the $\mathrm{NiO}$ was observed, rather low Faradaic efficiency of $6.2 \%$ and turnover number of 10 were recorded due to decomposition of the sensitizing $\mathrm{Zn}$ (II) porphyrin part. With the same strategy, Ishitani group reported a dye-sensitized photocathode where $\mathrm{Ru}(\mathrm{II})-\operatorname{Re}(\mathrm{I})$ dyads are anchored to $\mathrm{NiO}$ nanoparticles [129]. Enhanced Faradaic efficiency of $71 \%$ and turnover number of 32 were reported with the DS-PEC cell. Further improvement of Faradaic efficiency to $93 \%$ was achieved by replacing the $\mathrm{NiO}$ nanoparticles to $\mathrm{CuGaO}_{2}$ [130].

\section{Electrocatalysis}

In a broader context, electrocatalytic fuel producing systems wired to external power sources, e.g. photovoltaic cells, is also categorized as artificial photosynthesis. Immobilization of molecular catalysts on electrodes requires few requirements for successful electrocatalysis: (i) charge transfer between electrode surface and immobilizing matrix shoud be assured, (ii) the immobilizing matrix should act as a charge transfer channel, and (iii) substrates and products can freely diffuse in the bulk of immobilizing matrix. By fulfilling these requirements, a number of electrocatalytic systems for water splitting, $\mathrm{CO}_{2}$ reduction, or $\mathrm{O}_{2}$ reduction have been reported.

A number of studies have been made in the development of molecular catalysts for homogeneous water splitting and they are well reviewed previously [21, 131, 132]. The huge library of water splitting catalysts provides facile way to directly immobilize them on the electrode surfaces for electrocatalytic systems. Garrido-Barros et al. demonstrated electrocatalytic water oxidation with $\mathrm{Cu}$ (II) complexes strongly bound on the basal plane of graphene sheets (Fig. 8a) [133]. Comparative study

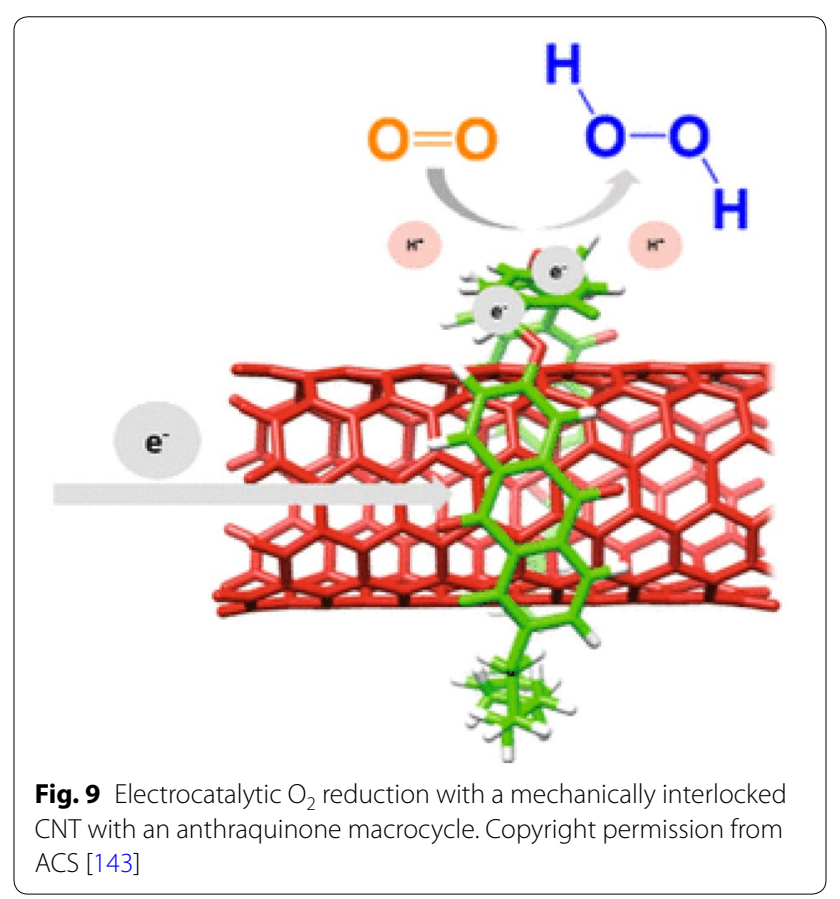

with the graphene-immobilized system $\left(\mathbf{G - 2} \mathbf{2}^{2-}\right)$ and a homogeneous system $\left(\mathbf{2}^{2-}\right)$ as a control showed remarkable increase in catalytic activity: $\mathbf{G - 2} \mathbf{2}^{\mathbf{2 -}}$ and $\mathbf{2}^{\mathbf{2 -}}$ showed maximum turnover frequencies of $540 \mathrm{~s}^{-1}$ and $128 \mathrm{~s}^{-1}$, respectively.

$\mathrm{CO}_{2}$ reduction in protic media inevitably competes with proton production, resulting in production of $\mathrm{H}_{2}$ as a byproduct. Interestingly, immobilization of electrocatalysts in solid matrices often enhances their selectivity to specific products by suppressing proton reduction. Wang and co-workers demonstrated highly selective $\mathrm{CO}_{2}$ 
electroreduction over $\mathrm{H}_{2}$ evolution with a $\mathrm{Cu}(\mathrm{I})$ complex adsorbed on graphene electrode [134]. It was proposed that the mesostructure of graphene favors diffusion of $\mathrm{CO}_{2}$ and limits mass transport of protons. More recently, $\mathrm{Zhu}$ and co-workers reported electrocatalytic $\mathrm{CO}_{2}$ reduction by immobilizing pyrrolidinonyl $\mathrm{Ni}$ (II) phthalocyanine (PyNiPc) on CNTs (Fig. 8b) [135]. The PyNiPc/ CNT catalyst suppressed $\mathrm{H} 2$ evolution and selectively promoted $\mathrm{CO}_{2}$ reduction; a high $\mathrm{CO} / \mathrm{H}_{2}$ value of 650 was recorded.

Anthraquinone and its derivatives and its derivatives have been explored as molecular electrocatalysts for $\mathrm{O}_{2}$ reduction, since anthraquinone is low-cost, has suitable chemical functionality, and high selectivity for $\mathrm{H}_{2} \mathrm{O}_{2}$ [136-139]. Attempts to immobilize anthraquinones on electrodes comprise: (i) directly linking to glassy carbon electrodes through covalent bonds [140], (ii) incorporating in insoluble polymer matrix [141], (iii) and covalently linking to CNTs [142]. Wielend et al.. demonstrated a new approach of "mechanically interlocking" anthraquinone-based catalysts around CNTs [143] The rotaxane architecture prevents dissolution problems of physically adsorbed organic molecules upon electrochemical reduction, while retains the electrochemical properties of the pristine molecule (Fig. 9).

\section{Summary and outlook}

The purpose of this review has been to understand the techniques to immobilize molecular catalysts in matrix-supports and incorporating them into artificial photosynthesis. Enhancement of catalytic activity and robustness was achieved with a simple chemistry using covalent bonds or non-covalent interactions. In addition, selectivity for specific product can be also enhanced by anchoring them in well-defined mesoporous structure. Synergetic effects were shown by hybridizing complementary molecular catalysts and solid supports.

The results provide a good blueprint for artificial photosynthesis; the researches so far are in a lab-scale and require next step forward for practical application of artificial photosynthesis in real life. Especially, proper device design is required to address the subjects listed below.

\subsection{Scalability}

The global production of $\mathrm{H}_{2}$ reached 790 Mton in 2018 (https://www.iea.org) and the $\mathrm{H}_{2} \mathrm{O}_{2}$ market valued 2.49 billion USD in 2019, (https://www.grandviewresearch.com). $\mathrm{H}_{2}$ and $\mathrm{H}_{2} \mathrm{O}_{2}$ are exclusively produced by natural gas reforming and anthraquinone process, respectively. Both of the methods require high energy input; renewable method, such as artificial photosynthesis, is desired to substitute the production. In this regard, scaled artificial photosynthesis with proper device design is required to comply with the large numbers. Atmospheric $\mathrm{CO}_{2}$ concentration of $420 \mathrm{ppm}$ is generally not high enough to directly run the catalytic reactions. The low $\mathrm{CO}_{2}$ solubility in water (ca. $1.5 \mathrm{~g} \mathrm{~L}^{-1}$ at the standard condition) also limits the scalability of $\mathrm{CO}_{2}$ reduction. Techniques such as gas-phase electrolysis coupled with flow cells are under development to circumvent the issue.

\subsection{Products separation}

Artificial photosynthesis comprises two half-reactions, resulting in at least two different products. In terms of monetary expenses, simple and cost-effective separation methods are required to separate a desired product from the admixture of reagents, substrates, and crude products. In water splitting, $\mathrm{H}_{2}$ and $\mathrm{O}_{2}$ are produced in a same phase of gas. Gas separation membranes are widely used to selectively collect $\mathrm{H}_{2}$ from the water splitting products. $\mathrm{CO}_{2}$ reduction is much more complicated due to a variety of possible products, vide supra. The gaseous mixture $\mathrm{CO}$ and $\mathrm{H}_{2}$ bubbles out from the reaction solution; it can be further separated or directly used as a syngas. The liquid phase separation requires rather high energy and complicated techniques.

Artificial photosynthesis is a promising, at the same time, a challenging subject. Multidisciplinary collaboration in chemistry, material science, biology, physics is required for successful realization of artificial photosynthesis.

\section{Abbreviations \\ CNT: Carbon nanotube; CuAAC: Cu'-catalyzed azide-alkyne cycloaddition; DS-PEC: Dye-sensitized photoelectrochemical; DSSC: Dye-sensitized solar cell; FG: Fluorinated graphene; GO: Graphene oxide; LC: Ligand-centered; LMCT: Ligand-to-metal charge transfer; MLCT: Metal-to-ligand charge transfer; MOF: Metal-organic framework; PEC: Photoelectrochemical; PSIIPSII: Photosystem II; rGO: Reduced graphene oxide; VLA-SC: Visible-light-absorbing semiconductor; WOC: Water oxidation catalyst.}

\section{Acknowledgements}

Not applicable.

\section{Authors' contributions}

DRW wrote the paper. He is the corresponding author of this paper.

Funding

This work was supported by the 2020 Industry-Academia Cooperation Program of Samsung Display and the Asian Office of Aerospace Research and Development (AOARD, FA 2386-17-1-4060, and FA 2386-15-1-4100).

Availability of data and materials

Not applicable.

Competing interests

The author declares no competing interests.

Received: 2 November 2020 Accepted: 23 November 2020

Published online: 30 November 2020 


\section{References}

1. T. Cardona, Heliyon 4, e00548 (2018)

2. L.H. Gade, P. Hofmann, Molecular Catalysts (Wiley-VCH Verlag GmbH \& Co. KGaA, Weinheim, Germany, 2014)

3. T. Liu, B. Zhang, L. Sun, Chem. - An Asian J. 14, 31 (2019)

4. P. Du, R. Eisenberg, Energy Environ. Sci. 5, 6012 (2012)

5. M.D. Kärkäs, O. Verho, E.V. Johnston, B. Åkermark, Chem. Rev. 114, 11863 (2014)

6. K.S. Joya, H.J.M. De Groot, Int. J. Hydrogen Energy 37, 8787 (2012)

7. N. Cox, W. Lubitz, in Chem. Energy Storage (DE GRUYTER, 2013)

8. J.L. Dempsey, J.R. Winkler, H.B. Gray, in Compr. Inorg. Chem. II (Second Ed. From Elem. to Appl. (Elsevier Ltd, 2013), pp. 553-565

9. T. Stoll, C.E. Castillo, M. Kayanuma, M. Sandroni, C. Daniel, F. Odobel, J. Fortage, M.N. Collomb, Coord. Chem. Rev. 304-305, 20 (2015)

10. L. Duan, L. Wang, F. Li, F. Li, L. Sun, Acc. Chem. Res. 48, 2084 (2015)

11. P. Garrido-Barros, C. Gimbert-Suriñach, R. Matheu, X. Sala, A. Llobet, Chem. Soc. Rev. 46, 6088 (2017)

12. S.M. Lauinger, Q. Yin, Y.V. Geletii, C.L. Hill, in Adv. Inorg. Chem. (Academic Press Inc., 2017), pp. 117-154

13. K. Elouarzaki, V. Kannan, V. Jose, H.S. Sabharwal, J. Lee, Adv. Energy Mater. 9, 1900090 (2019)

14. C.-F. Leung, P.-Y. Ho, Catalysts 9, 760 (2019)

15. P. Gotico, Z. Halime, A. Aukauloo, Dalt. Trans. 49, 2381 (2020)

16. F. Wang, ChemSusChem 10, 4393 (2017)

17. M.R. Dubois, D.L. Dubois, Acc. Chem. Res. 42, 1974 (2009)

18. C. Finn, S. Schnittger, L.J. Yellowlees, J.B. Love, Chem. Commun. 48, 1392 (2012)

19. N. Elgrishi, M.B. Chambers, X. Wang, M. Fontecave, Chem. Soc. Rev. 46 761 (2017)

20. H. Takeda, C. Cometto, O. Ishitani, M. Robert, ACS Catal. 7, 70 (2017)

21. J.W. Wang, W.J. Liu, D.C. Zhong, T.B. Lu, Coord. Chem. Rev. 378, 237 (2019)

22. C.W. Machan, ACS Catal. 10, 2640 (2020)

23. E. Anxolabéhère-Mallart, F. Banse, Curr. Opin. Electrochem. 15, 118 (2019)

24. V. Artero, M. Fontecave, Chem. Soc. Rev. 42, 2338 (2013)

25. P. Jordan, P. Fromme, H.T. Witt, O. Klukas, W. Saenger, N. Krauß, Nature 411, 909 (2001)

26. A. Amunts, H. Toporik, A. Borovikova, N. Nelson, J. Biol. Chem. 285, 3478 (2010)

27. S. Järvi, M. Suorsa, E.M. Aro, Biochim. Biophys. Acta - Bioenerg. 1847, 900 (2015)

28. E.J. Boekema, H. Van Roon, F. Calkoen, R. Bassi, J.P. Dekker, Biochemistry 38, 2233 (1999)

29. C.P. Andrieux, F. Gonzalez, J.M. Savéant, J. Am. Chem. Soc. 119, 4292 (1997)

30. Y.C. Liu, R.L. McCreery, J. Am. Chem. Soc. 117, 11254 (1995)

31. P. Allongue, M. Delamar, B. Desbat, O. Fagebaume, R. Hitmi, J. Pinson, J.M. Savéant, J. Am. Chem. Soc. 119, 201 (1997)

32. M. Delamar, R. Hitmi, J. Pinson, J. Savéant, J. Am. Chem. Soc. 114, 5883 (1992)

33. J. Pinson, F. Podvorica, Chem. Soc. Rev. 34, 429 (2005)

34 A. Sarapuu, K. Helstein, D.J. Schififrin, K. Tammeveski, Electrochem. SolidState Lett. 8, 22 (2005)

35 F. Mirkhalaf, K. Tammeveski, D.J. Schiffrin, Phys. Chem. Chem. Phys. 13 21 (2004)

36. K. Vaik, A. Sarapuu, K. Tammeveski, F. Mirkhalaf, D.J. Schiffrin, J. Electroanal. Chem. 564, 159 (2004)

37. K. Vaik, D.J. Schiffrin, K. Tammeveski, Electrochem. Commun. 6, 1 (2004)

38. A. Sarapuu, K. Vaik, D.J. Schiffrin, K. Tammeveski, J. Electroanal. Chem. 541, 23 (2003)

39. K. Tammeveski, K. Kontturi, R.J. Nichols, R.J. Potter, D.J. Schiffrin, J. Electroanal. Chem. 515, 101 (2001)

40. C.P. Andrieux, F. Gonzalez, J.M. Savéant, J. Electroanal. Chem 498, 171 (2001)

41. E. Coulon, J. Pinson, J.D. Bourzat, A. Commerçon, J.P. Pulicani, Langmuir 17, $7102(2001)$

42. M. Galicia, F.J. González, J. Electrochem. Soc. 149, D46 (2002)

43. F. Geneste, C. Maël, C. Moinet, G. Jezequel, New J. Chem. 26, 1261 (2002)

44. P.E. Fanning, M.A. Vannice, Carbon N. Y. 31, 721 (1993)
45. V. Urbanová, K. Holá, A.B. Bourlinos, K. Čépe, A. Ambrosi, A.H. Loo, M. Pumera, F. Karlický, M. Otyepka, R. Zbořil, Adv. Mater. 27, 2305 (2015)

46. B. Li, T. He, Z. Wang, Z. Cheng, Y. Liu, T. Chen, W. Lai, X. Wang, X. Liu, Phys. Chem. Chem. Phys. 18, 17495 (2016)

47. C. Bosch-Navarro, M. Walker, N.R. Wilson, J.P. Rourke, J. Mater. Chem. C 3 7627 (2015)

48. K.E. Whitener, R. Stine, J.T. Robinson, P.E. Sheehan, J. Phys. Chem. C 119 10507 (2015)

49. R. Stine, J.W. Ciszek, D.E. Barlow, W.K. Lee, J.T. Robinson, P.E. Sheehan, Langmuir 28, 7957 (2012)

50. P. Lazar, C.K. Chua, K. Holá, R. Zbořil, M. Otyepka, M. Pumera, Small 11, $3790(2015)$

51. X. Ye, L. Ma, Z. Yang, J. Wang, H. Wang, S. Yang, ACS Appl. Mater. Interfaces 8,7483 (2016)

52. R.R. Nair, W. Ren, R. Jalil, I. Riaz, V.G. Kravets, L. Britnell, P. Blake, F. Schedin, A.S. Mayorov, S. Yuan, M.I. Katsnelson, H.M. Cheng, W. Strupinski, L.G. Bulusheva, A.V. Okotrub, I.V. Grigorieva, A.N. Grigorenko, K.S. Novoselov, A.K. Geim, Small 6, 2877 (2010)

53. A.B. Bourlinos, K. Safarova, K. Siskova, R. Zbořil, Carbon N. Y. 50, 1425 $(2012)$

54. D.D. Chronopoulos, A. Bakandritsos, M. Pykal, R. Zbořil, M. Otyepka, Appl. Mater. Today 9, 60 (2017)

55. E.D. Stenehjem, V.R. Ziatdinov, T.D.P. Stack, C.E.D. Chidsey, J. Am. Chem. Soc. 135, $1110(2013)$

56. M.A. Pellow, T.D.P. Stack, C.E.D. Chidsey, Langmuir 29, 5383 (2013)

57. A. Devadoss, C.E.D. Chidsey, J. Am. Chem. Soc. 129, 5370 (2007)

58 C. De Wu, M. Zhao, Adv. Mater. 29, 87 (2017)

59 C. Janiak, J. Chem. Soc. Dalt. Trans. 38, 85 (2000)

60. M.R. Axet, J. Durand, M. Gouygou, P. Serp, in Adv. Organomet. Chem. (Academic Press Inc., 2019), pp. 53-174

61. H. Jaegfeldt, T. Kuwana, G. Johansson, J. Am. Chem. Soc. 105, 1805 (1983)

62. L. Zhang, E. Yue, B. Liu, P. Serp, C. Redshaw, W.H. Sun, J. Durand, Catal. Commun. 43, 227 (2014)

63 L. Zhang, W. Zhang, P. Serp, W.-H. Sun, J. Durand, ChemCatChem 6, 12 (2014)

64 R.J. Chen, Y. Zhang, D. Wang, H. Dai, J. Am. Chem. Soc. 123, 3838 (2001)

65 V. Georgakilas, J.N. Tiwari, K.C. Kemp, J.A. Perman, A.B. Bourlinos, K.S. Kim, R. Zboril, Chem. Rev. 116, 5464 (2016)

66 R.M. Tromp, A. Afzali, M. Freitag, D.B. Mitzi, Z. Chen 26, 18 (2020)

67. J.S. Foster, J.E. Frommer, Nature 333, 542 (1988)

68. A.J. Pollard, E.W. Perkins, N.A. Smith, A. Saywell, G. Goretzki, A.G. Phillips, S.P. Argent, H. Sachdev, F. Müller, S. Hüfner, S. Gsell, M. Fischer, M. Schreck, J. Osterwalder, T. Greber, S. Berner, N.R. Champness, P.H. Beton, Angew. Chemie - Int. Ed. 49, 1794 (2010)

69. P. Lauffer, K.V. Emtsev, R. Graupner, T. Seyller, L. Ley, Phys. Status Solidi 245, 2064 (2008)

70. H. Huang, S. Chen, X. Gao, W. Chen, A.T.S. Wee, ACS Nano 3, 3431 (2009)

71. Y. Zhang, C. Liu, W. Shi, Z. Wang, L. Dai, X. Zhang, Langmuir 23, 7911 (2007)

72. Y. Liang, D. Wu, X. Feng, K. Müllen, Adv. Mater. 21, 1679 (2009)

73. E.Y. Choi, T.H. Han, J. Hong, J.E. Kim, S.H. Lee, H.W. Kim, S.O. Kim, J. Mater. Chem. 20, 1907 (2010)

74. H. Dau, M. Haumann, Coord. Chem. Rev. 252, 273 (2008)

75. D.R. Whang, S.Y. Park, ChemSusChem 8, 3204 (2015)

76. J. Kim, D.R. Whang, S.Y. Park, ChemSusChem 10, 1883 (2017)

77. D.R. Whang, D.H. Apaydin, S.Y. Park, N.S. Sariciftci, J. Catal. 363, 191 (2018)

78. A. Pannwitz, O.S. Wenger, Chem. Commun. 55, 4004 (2019)

79. S. Karlsson, J. Boixel, Y. Pellegrin, E. Blart, H.C. Becker, F. Odobel, L. Hammarström, Faraday Discuss. 155, 233 (2012)

80. J.J. Du, Y.P. Yuan, J.X. Sun, F.M. Peng, X. Jiang, L.G. Qiu, A.J. Xie, Y.H. Shen, J.F. Zhu, J. Hazard. Mater. 190, 945 (2011)

81. K.G.M. Laurier, F. Vermoortele, R. Ameloot, D.E. De Vos, J. Hofkens, M.B.J. Roeffaers, J. Am. Chem. Soc. 135, 14488 (2013)

82. C.G. Silva, I. Luz, F.X. Llabrés, I. Xamena, A. Corma, H. García, Chem. - A Eur. J. 16, 11133 (2010)

83. M. Alvaro, E. Carbonell, B. Ferrer, F.X. Llabrés, I. Xamena, H. Garcia, Chem. - A Eur. J. 13, 5106 (2007)

84. F.X. Llabrés i Xamena, A. Corma, H. Garcia, J. Phys. Chem. C 111, 80 (2007) 
85. J. Gao, J. Miao, P.Z. Li, W.Y. Teng, L. Yang, Y. Zhao, B. Liu, Q. Zhang, Chem Commun. 50, 3786 (2014)

86. E.Y. Lee, S.Y. Jang, M.P. Suh, J. Am. Chem. Soc. 127, 6374 (2005)

87. H.K. Chae, J. Kim, O.D. Friedrichs, M. O'Keeffe, O.M. Yaghi, Angew. Chemie - Int. Ed. 42, 3907 (2003)

88. M.H. Xie, X.L. Yang, C. Zou, C. De Wu, Inorg. Chem. 50, 5318 (2011)

89. C. Wang, Z. Xie, K.E. Dekrafft, W. Lin, J. Am. Chem. Soc. 133, 13445 (2011)

90. H.Q. Xu, J. Hu, D. Wang, Z. Li, Q. Zhang, Y. Luo, S.H. Yu, H.L. Jiang, J. Am. Chem. Soc. 137, 13440 (2015)

91. Z. Bin Fang, T.T. Liu, J. Liu, S. Jin, X.P. Wu, X.Q. Gong, K. Wang, Q. Yin, T.F. Liu, R. Cao, H.C. Zhou, J. Am. Chem. Soc. 142, 12515 (2020)

92. D. Sun, Y. Fu, W. Liu, L. Ye, D. Wang, L. Yang, X. Fu, Z. Li, Chem. - A Eur. J. 19, 14279 (2013)

93. Y. Fu, D. Sun, Y. Chen, R. Huang, Z. Ding, X. Fu, Z. Li, Angew. Chemie - Int. Ed. 51, 3364 (2012)

94. C. Wang, Z. Xie, K.E. Dekrafft, W. Lin, J. Am. Chem. Soc. 133, 13445 (2011)

95. D. Kim, D.R. Whang, S.Y. Park, J. Am. Chem. Soc. 138, 8698 (2016)

96. C.N. Valdez, A.M. Schimpf, D.R. Gamelin, J.M. Mayer, J. Am. Chem. Soc. 138, 1377 (2016)

97. H. Tong, S. Ouyang, Y. Bi, N. Umezawa, M. Oshikiri, J. Ye, Adv. Mater. 24 229 (2012)

98. A. Kudo, Y. Miseki, Chem. Soc. Rev. 38, 253 (2009)

99. E. B. and and W. Choi*, (2006)

100. K. Hirano, E. Suzuki, A. Ishikawa, T. Moroi, H. Shiroishi, M. Kaneko, J. Photochem. Photobiol. A Chem. 136, 157 (2000)

101. H.Q. Zheng, H. Yong, O.Y. Ting, Y.T. Fan, H.W. Hou, in Int. J. Hydrogen Energy (Pergamon, 2013), pp. 12938-12945

102. K. Maeda, G. Sahara, M. Eguchi, O. Ishitani, ACS Catal. 5, 1700 (2015)

103. E. Bae, W. Choi, J. Park, H.S. Shin, S.Bin Kim, J.S. Lee, J. Phys. Chem. B 108, $14093(2004)$

104. Y.J. Yuan, J.R. Tu, Z.J. Ye, H.W. Lu, Z.G. Ji, B. Hu, Y.H. Li, D.P. Cao, Z.T. Yu, Z.G. Zou, Dye. Pigment. 123, 285 (2015)

105. M. Zhu, Z. Li, B. Xiao, Y. Lu, Y. Du, P. Yang, X. Wang, ACS Appl. Mater. Interfaces 5, 1732 (2013)

106. L. Zhang, L. Qin, S.Z. Kang, G.D. Li, X. Li, ACS Sustain. Chem. Eng. 7, 8358 (2019)

107. A. Fujishima, K. Honda, Bull. Chem. Soc. Jpn 44, 1148 (1971)

108. A. Fujishima, K. Honda, Nature 238, 37 (1972)

109. A.G. Tamirat, J. Rick, A.A. Dubale, W.N. Su, B.J. Hwang, Nanoscale Horizons 1, 243 (2016)

110. O. Khaselev, J.A. Turner, Science (80-.). 280, 425 (1998)

111. B. O'Regan, M. Grätzel, Nature 353, 737 (1991)

112. Z. Yu, F. Li, L. Sun, Energy Environ. Sci. 8, 760 (2015)

113. J.W. Youngblood, S.H.A. Lee, Y. Kobayashi, E.A. Hernandez-Pagan, P.G. Hoertz, T.A. Moore, A.L. Moore, D. Gust, T.E. Mallouk, J. Am. Chem. Soc. 131, 926 (2009)

114. J.J. Concepcion, J.W. Jurss, P.G. Hoertz, T.J. Meyer, Angew. Chemie - Int Ed. 48, 9473 (2009)

115. R. Brlmblecombe, A. Koo, G.C. Dismukes, G.F. Swlegers, L. Spiccia, J. Am. Chem. Soc. 132, 2892 (2010)

116. D.L. Ashford, A.M. Lapides, A.K. Vannucci, K. Hanson, D.A. Torelli, D.P. Harrison, J.L. Templeton, T.J. Meyer, J. Am. Chem. Soc. 136, 6578 (2014)

117. D.L. Ashford, B.D. Sherman, R.A. Binstead, J.L. Templeton, T.J. Meyer, Angew. Chemie Int. Ed. 54, 4778 (2015)

118. M.V. Sheridan, B.D. Sherman, R.L. Coppo, D. Wang, S.L. Marquard, K.R. Wee, N.Y. Murakami, Iha, T.J. Meyer, ACS Energy Lett. 1, 231 (2016)

119. B.D. Sherman, Y. Xie, M.V. Sheridan, D. Wang, D.W. Shaffer, T.J. Meyer, J.J. Concepcion, ACS Energy Lett. 2, 124 (2017)
120. L. Li, L. Duan, Y. Xu, M. Gorlov, A. Hagfeldt, L. Sun, Chem. Commun. 46 $7307(2010)$

121. G.F. Moore, J.D. Blakemore, R.L. Milot, J.F. Hull, H.E. Song, L. Cai, C.A. Schmuttenmaer, R.H. Crabtree, G.W. Brudvig, Energy Environ. Sci. 4, 2389 (2011)

122. W. Song, C.R.K. Glasson, H. Luo, K. Hanson, M.K. Brennaman, J.J. Concepcion, T.J. Meyer, J. Phys. Chem. Lett. 2, 1808 (2011)

123. D.L. Ashford, W. Song, J.J. Concepcion, C.R.K. Glasson, M.K. Brennaman, M.R. Norris, Z. Fang, J.L. Templeton, T.J. Meyer, J. Am. Chem. Soc. 134 19189 (2012)

124. K. Hanson, D.A. Torelli, A.K. Vannucci, M.K. Brennaman, H. Luo, L. Alibabaei, W. Song, D.L. Ashford, M.R. Norris, C.R.K. Glasson, J.J. Concepcion, T.J. Meyer, Angew. Chemie - Int. Ed. 51, 12782 (2012)

125. M.R. Norris, J.J. Concepcion, Z. Fang, J.L. Templeton, T.J. Meyer, Angew. Chemie Int. Ed. 52, 13580 (2013)

126. A.M. Lapides, D.L. Ashford, K. Hanson, D.A. Torelli, J.L. Templeton, T.J. Meyer, J. Am. Chem. Soc. 135, 15450 (2013)

127. X. Ding, Y. Gao, L. Zhang, Z. Yu, J. Liu, L. Sun, ACS Catal. 4,2347 (2014)

128. Y. Kou, S. Nakatani, G. Sunagawa, Y. Tachikawa, D. Masui, T. Shimada, S. Takagi, D.A. Tryk, Y. Nabetani, H. Tachibana, H. Inoue, J. Catal. 310, 57 (2014)

129. G. Sahara, R. Abe, M. Higashi, T. Morikawa, K. Maeda, Y. Ueda, O. Ishitani, Chem. Commun. 51, 10722 (2015)

130. H. Kumagai, G. Sahara, K. Maeda, M. Higashi, R. Abe, O. Ishitani, Chem. Sci. 8,4242 (2017)

131. J.D. Blakemore, R.H. Crabtree, G.W. Brudvig, Chem. Rev. 115, 12974 (2015)

132. M. Yagi, M. Kaneko, Chem. Rev. 101, 21 (2001)

133. P. Garrido-Barros, C. Gimbert-Surinifach, D. Moonshiram, A. Picón, P. Monge, V.S. Batista, A. Llobet, J. Am. Chem. Soc. 139, 12907 (2017)

134. J. Wang, L. Gan, Q. Zhang, V. Reddu, Y. Peng, Z. Liu, X. Xia, C. Wang, X. Wang, Adv. Energy Mater. 9, 1803151 (2019)

135. D.D. Ma, S.G. Han, C. Cao, X. Li, X.T. Wu, Q.L. Zhu, Appl. Catal. B Environ. 264, $118530(2020)$

136. G. Goor, J. Glenneberg, S. Jacobi, J. Dadabhoy, E. Candido, Ullmann's Encycl. Ind. Chem (Wiley-VCH Verlag GmbH \& Co. KGaA, Weinheim, Germany, 2019), pp. 1-40

137. F. Mirkhalaf, K. Tammeveski, D.J. Schiffrin, Phys. Chem. Chem. Phys. 6 $1321(2004)$

138. K. Tammeveski, K. Kontturi, R.J. Nichols, R.J. Potter, D.J. Schiffrin, J. Electroanal. Chem. 515, 101 (2001)

139. A. Sarapuu, K. Helstein, K. Vaik, D.J. Schiffrin, K. Tammeveski, Electrochim. Acta 55, $6376(2010)$

140. K. Vaik, U. Mäeorg, F.C. Maschion, G. Maia, D.J. Schiffrin, K. Tammeveski, in Electrochim. Acta (Pergamon, 2005), pp. 5126-5131

141. P.M. Hoang, S. Holdcroft, B.L. Funt, J. Electrochem. Soc. 132, 2129 (1985)

142. M. Mooste, E. Kibena-Pöldsepp, L. Matisen, K. Tammeveski, Electroanalysis $\mathbf{2 9}, 548$ (2017)

143. D. Wielend, M. Vera-Hidalgo, H. Seelajaroen, N.S. Sariciftci, E.M. Pérez, D.R. Whang, ACS Appl. Mater. Interfaces 12, 32615 (2020)

\section{Publisher's Note}

Springer Nature remains neutral with regard to jurisdictional claims in published maps and institutional affiliations. 